\title{
Interdependence between Managerial Ownership, Leverage and Firm Value: Theory and Empirical Validation
}

\author{
Ben Said Hatem ${ }^{1}$ \\ ${ }^{1}$ Faculty of Law, Economics and Management of Jendouba, University of Jendouba, Jendouba, Tunisia \\ Correspondence: Ben Said Hatem, Faculty of Law, Economics and Management of Jendouba, University of \\ Jendouba, Jendouba, Tunisia. E-mail: hatbensaid@ gmail.com
}

Received: April 15, 2015

Accepted: November 19, 2015

Online Published: November 25, 2015

doi:10.5539/ijef.v7n12p106

URL: http://dx.doi.org/10.5539/ijef.v7n12p106

\begin{abstract}
This paper test the interdependence between managerial ownership, debt and firm value. To this end, we examined a sample of 246 French firms over a period of 11 years is built. In addition, we use two estimation methods: simultaneous equations and data panels methods. The empirical results support the interaction between these three variables. We concluded a nonlinear relationship between insider ownership and shareholder wealth. An inverse U-shaped relationship was found between debt and managerial ownership. However, an increase in debt leads to an increase in managerial ownership. Moreover, the share capital held by managers is a significant factor in explaining debt ratio of French firms. Finally, we conclude that the disciplinary role of debt is valid only for the data panels method.
\end{abstract}

Keywords: leverage, managerial ownership, firm value, interdependence, disciplinary role

\section{Introduction}

Most authors have examined the impact of debt on firm value (Dimitris \& Psillak, 2010). However, Kai Heng and Longkai (2009) studied the impact of ownership structure on firm debt. Their results indicate that the state ownership positively affects firm's debt ratio. Similarly, Hubert (2012) examines the relationship between debt and ownership structure in the French market. The author found a nonlinear relationship between first shareholders and debt. Moreover, there are other studies that explain the determinants of ownership structure. Indeed, Ansgar and Christian (2013) test the factors explaining ownership concentration for public firms. Particularly following the methodology developed by Thomsen and Pedersen (2000), they measure the effect of capital structure on the ownership structure. As a measure of capital structure, they used the debt over total assets ratio. From these studies, we conclude to the existence of a relationship between shareholder wealth, capital structure and ownership structure. Our aim is to test the interdependence between managerial ownership, firm value and leverage. The next section will present the literature review. In section three, we introduce our sample, as well as the models we use to test our variables. Section 4 interprets our empirical results. An analysis of the effects of industries and growth opportunities on the relationship between debt and firm value will be presented in Section 5. The final section concludes with our main empirical results.

\section{The Literature Review}

Numerous empirical works have analyzed the interdependence between debt, managerial ownership and firm value. Modigliani and Miller (1963) found that firm value is an increasing function of the debt ratio due to the effects of income tax savings. Harris and Raviv (1991), Mauer and Triantis (1994) and Zingales (1995) used dynamic models and did not conclude to the existence of a target capital structure ratio.

Following the methodology of La Porta, Lopez, and Shleifer (1999) and Claessens, Djankov, and Lang (2000) Ariffin, Mat, and McGowan (2010) examined the influence of the separation between ownership and control on the relationship between debt and shareholder wealth. Accordingly, the authors studied the interaction between firm value, capital structure and ownership structure using simultaneous equations methods. Using the method of Triple Least Square, the empirical results indicated that separating ownership and control leads to higher levels of debt ratio. In addition, the authors concluded that the leverage negatively and significantly affects firm value because of existence of bankruptcy costs.

The work of David and Diane (2006) is based on the empirical work of Myers (1977), Jensen (1986), Stulz (1990), 
Lang and Stulz. (1996) and Peyer and Shivdasani (2001) who tested the relationship between debt and investment, as well as the work of McConnell and Servaes $(1990,1995)$ who analyzed the impact of debt on firm value. David and Diane (2006) tested the impact of debt on firm value. Examining a sample of 8674 American firms over a period of 16 years from 1982 to 1997, David and Diane (2006) found results similar to those of McConnell and Servaes (1995). The results indicate that for firms with low levels of growth opportunities, debt positively affects firm value. However, for firms with high levels of growth opportunities, debt inversely relates to firm value.

Like Ferreira, Massa, and Matos (2010), Chung, Firth, and Kim (2002), Hsu and Koh (2005), Wang (2014), Chan Lin, Chang, and Liao (2013), Tai Lai, and Lin (2014), Chune Kainan (2014)examined the interdependence between ownership structure and debt ratio. Specifically, the authors examined the effect of capital held by shareholders firms. Obtained through simultaneous equations model, the empirical results show a negative and a statistically significant effect of ownership structure on the debt ratio. Finally, the authors find a negative relationship between variation of capital structure and variation of ownership structure.

\section{Data and Methodology}

\subsection{Selection of the Sample}

Our sample consists of 246 non financial French firms during a period of 11 years from 1997 to 2007 (industrial: 115 firms; trade:42 firms; transportation: 20 firms; oil: 17 firms; service: 52 firms). To collect our data, we used several sources of information, including, "DTATSTREAM", "MERGENTONLINE", "FMI". Specifically, data on ownership structure are obtained from the annual reports of companies available in "MERGENTONLINE" database.

\subsection{Simultaneous Equations Tested}

In our paper, we test in a long-term framework interdependence between ownership structure, leverage and firm value through the model of Saibal Ghosh (2007).

\subsection{Measures of Variables and Research Hypothesis}

In what follows we define our variables and their expected effects. Following our hypothesis, independent variables and, the methodology advanced by Saibal Ghosh (2007), we test the following models:

$$
\begin{aligned}
& D R_{i t}=\alpha_{0}+\alpha_{1} M O_{i t}+\alpha_{2} M_{S O}^{2}+\alpha_{3} A D J \mathrm{Q}_{\mathrm{it}}+\alpha_{4} \text { LogAssets }_{i t}+\alpha_{5} \operatorname{LogAge}_{i t}+\alpha_{6} R \& D_{i t} \\
& +\alpha_{7} \text { Tangible }_{i t}+\alpha_{8} \text { Cash Flow }_{i t}+\alpha_{9} \text { TS }_{i t}+\alpha_{10} \text { VOLTY }_{i t}+\varepsilon_{i t} \\
& M S O_{i t}=\beta_{0}+\beta_{1} D R_{i t}+\beta_{2} A D J \mathrm{Q}_{i t}+\beta_{3} \operatorname{LogMve}_{i t}+\beta_{4} \operatorname{LogAge}_{i t}+\beta_{5} \text { TANGIBLE }_{i t} \\
& +\beta_{6} R \& D_{i t}+\beta_{7} D I V_{i t}+\beta_{8} V_{O L T Y}+\varepsilon_{i t} \\
& \operatorname{Adj} \mathrm{Q}_{\mathrm{it}}=\gamma_{0}+\gamma_{1} \mathrm{MSO}_{i t}+\gamma_{2} \mathrm{MSO}_{i t}^{2}+\gamma_{3} \mathrm{DR}_{i t}+\gamma_{4} \text { LogAssets }_{i t}+\gamma_{5} \text { LogAge }_{i t}+\gamma_{6} R \& D_{i t} \\
& +\gamma_{7} R O A_{i t}+\varepsilon_{i t}
\end{aligned}
$$

However, to test the effect of activity sectors on the disciplinary role of debt, we used the following models:

$$
\begin{aligned}
& D R_{i t}=\alpha_{0}+\alpha_{1} M_{S O} O_{i t}+\alpha_{2} M S O_{i t}^{2}+\alpha_{3} A D J \mathrm{Q}_{\mathrm{it}}+\alpha_{4} \operatorname{LogAssets}_{i t}+\alpha_{5} \operatorname{LogAge}_{i t}+\alpha_{6} R \& D_{i t} \\
& +\alpha_{7} \text { Tangible }_{i t}+\alpha_{8} \text { Cash Flow }_{i t}+\alpha_{9} \text { TS }_{i t}+\alpha_{10} \text { VOLTY }_{i t}+\varepsilon_{i t} \\
& M S O_{i t}=\beta_{0}+\beta_{1} D R_{i t}+\beta_{2} A D J \mathrm{Q}_{i t}+\beta_{3} \operatorname{LogMve}_{i t}+\beta_{4} \text { LogAge }_{i t}+\beta_{5} \text { TANGIBLE }_{i t} \\
& +\beta_{6} R \& D_{i t}+\beta_{7} D I V_{i t}+\beta_{8} \operatorname{VOLTY}_{i t}+\varepsilon_{i t} \\
& \operatorname{Adj} \mathrm{Q}_{\mathrm{it}}=\gamma_{0}+\gamma_{1} M S O_{i t}+\gamma_{2} M S O_{i t}^{2}+\gamma_{3} P E T * D R_{i t}+\gamma_{4} I N D * D R_{i t}+\gamma_{5} T R A^{*} D R_{i t}+\gamma_{6} C O M M * D R_{i t} \\
& +\gamma_{7} \text { SER }^{*} D R_{i t}+\gamma_{8} \text { LogAssets }_{i t}+\gamma_{9} \operatorname{LogAge}_{i t}+\gamma_{10} R \& D_{i t}+\gamma_{11} R O A_{i t}+\varepsilon_{i t}
\end{aligned}
$$

Finally, to test the effect of opportunities growth on the disciplinary role of debt, the following models:

$$
\begin{aligned}
& D R_{i t}=\alpha_{0}+\alpha_{1} \text { MSO }_{i t}+\alpha_{2} \text { MSO }_{i t}^{2}+\alpha_{3} \text { ADJ } \mathrm{Q}_{i t}+\alpha_{4} \text { LogAssets }_{i t}+\alpha_{5} \text { LogAge }_{i t}+\alpha_{6} R \& D_{i t} \\
& +\alpha_{7} \text { Tangible }_{i t}+\alpha_{8} \text { Cash Flow }_{i t}+\alpha_{9} \text { TS }_{i t}+\alpha_{10} \text { VOLTY }_{i t}+\varepsilon_{i t}
\end{aligned}
$$




$$
\begin{aligned}
& M S O_{i t}=\beta_{0}+\beta_{1} D R_{i t}+\beta_{2} A D J \mathrm{Q}_{i t}+\beta_{3} \operatorname{LogMve}_{i t}+\beta_{4} \operatorname{LogAge}_{i t}+\beta_{5} \text { TANGIBLE }_{i t} \\
& +\beta_{6} R \& D_{i t}+\beta_{7} D I V_{i t}+\beta_{8} V O L T Y_{i t}+\varepsilon_{i t} \\
& \operatorname{Adj} \mathrm{Q}_{\mathrm{it}}=\gamma_{0}+\gamma_{1} \mathrm{MSO}_{i t}+\gamma_{2} M S O_{i t}^{2}+\gamma_{3} D R_{i t}+\gamma_{4} \phi_{i} * D R_{i t}+\gamma_{5} \operatorname{LogAssets}_{i t}+\gamma_{6} \operatorname{LogAge}_{i t}+\gamma_{7} R \& D_{i t} \\
& +\gamma_{8} R O A_{i t}+\varepsilon_{i t}
\end{aligned}
$$

For the dummy variable, “ $\phi_{i}$ ", we use, alternatively, “ $\phi_{1}$ " and" $\phi_{2}$ ", as defined below.

\subsubsection{The Dependant Variables}

Managerial ownership: In our study, we measure insider ownership as the share of capital held by members of the Board of Directors. Jensen and Meckling (1976) consider that, for low levels of managerial ownership, there is a positive relationship between managerial ownership and debt. In contrast, Stulz (1990) argues that for high levels, managerial ownership negatively affects firm's debt ratio. Hypothesis 1: There is a nonlinear relationship between insider ownership (repartition of shares) and debt ratio. in the same way, Morck, Shleifer and Vishny (1988) conclude a nonlinear relationship between managerial ownership and firm value. Hypothesis 2: There is a nonlinear relationship between distribution of shares between shareholders and firm value

Leverage: Leverage is defined as the sum of long-term and short-term debt divided by total assets. Leverage can affects positively or negatively managerial ownership. Hypothesis 3: Leverage positively or negatively affects managerial ownership. A high debt aligns the interests of shareholders and managers. Hypothesis 4: Leverage positively affects firm value.

Firm value: Following the methodology of Kingand Santor (2008), we use the Tobin's Q to measure firm value. This ratio is defined as the market value of equity plus long-term debt divided by total assets. Jensen (1986) and Grossman and Hart (1982) suggest a negative relationship between debt equity ratio and firm value. Hypothesis 5: Firm value negatively affects leverage. A higher firm value stimulate managers to increase their managerial ownership. Hypothesis 6: Firm value positively affects managerial ownership.

\subsubsection{The Independent Variables}

Firm Size: Firm size is measured by the logarithm of total assets. Alternatively, to measure firm size, we use the logarithm of market capitalization. According to Rajan and Zingales (1995), higher firm size encourages firms to finance their projects by issuing new shares, which implies a lower debt level. Hypothesis 7: The size negatively affects firm's debt ratio. Similarly, in the second equation, the larger the firm, the more difficult it is for managers to increase their capital shares (Saibal \& Ghosh, 20017). Hypothesis 8: Firm size negatively affects the managerial ownership. Similarly, in the second equation, a higher size makes a good signal on firm management. Hypothesis 9: Firm size positively affects firm value.

Firm age: As a control variable, we use the logarithm of firm age. In Tufano (1996), the debt is inversely relates to firm age. Hypothesis 10: The age negatively affects firm's debt ratio. In the second equation, a higher age may mean higher growth opportunities. In this case, managers will benefit by increasing their capital shares. Hypothesis 11: Firm age positively affects managerial ownership. Similarly, firm age informs about firm's profitability and financial health. Therefore, we may hypothesize for a positive relationship between age and firm value. Hypothesis 12: The age positively affects firm value.

Research and development ratio: Research and development ratio is approximated by the research and development expenditures divided by total assets. A higher amounts of research and development expenses leads to a little amount of liquidity. For deficit financing, firms may have higher values of debt. Hypothesis 13: Expenditure on research and development positively affects firm's debt ratio. In the second equation, high costs of research and development may increase the firm's future profitability, which will positively affect the managerial ownership. Hypothesis 14: Expenditure on research and development positively affects managerial ownership. In the same way, we may hypothesize for a positive relationship between spending on research and development and firm value. Lin, Lee, Huang (2006) suggest a positive relationship between R\&D ratio and firm value. Hypothesis 15: Expenditure on research and development positively affects firm value.

Tangibles assets: Assets tangibility is measured as the sum of the fixed assets of the firm divided by total assets. Indeed, tangible assets are considered collateral for lenders. Hypothesis 16: Tangible assets positively affects firm's debt ratio. In the second equation, a large amount of tangible assets means good management of the firm. This means a higher financial performance of the firm. In this case, the managers will try to increase their capital shares. Hypothesis 17: Tangibility of assets positively affects managerial ownership. 
Cash flow: Cash flows represent net income plus depreciation, amortization and provisions divided by total assets. A higher amount of cash flow means more cash for the company, which will negatively affect the debt ratio (Miroslav, Panikkos, \& Konstantin, 2013). Hypothesis 18: Cash flows negatively affects the firm's debt ratio.

Tax savings: The tax savings are defined as the ratio of earnings before interest and taxes on total assets. Like MacKie-Mason (1990), we expect a negative relationship between debt and tax savings. Hypothesis 19: The tax savings negatively affect debt firm's ratio.

Volatility: Volatility is approximated by the standard deviation of changes in share prices. Higher volatility leads to higher bankruptcy risk, which will reduce firm debt. Hypothesis 20: Volatility negatively affects firm debt. In the second equation, managers are always looking to make safe investments. Therefore, with an increase in volatility, managers reduce their capital shares. Hypothesis 21: Volatility negatively affects managerial ownership.

Dividends: Unlike Benartzi, Michaely, and Thaler (1997), Eckbo and Verman (1994), Gul (1999) and William, Chao, Song (2013), dividends are measured as total dividends paid on total assets. A high amount of dividends can stimulate managers to buy more shares of the firm. Hypothesis 22: There is a positive relationship between dividends and managerial ownership.

Return on assets: The return on assets is defined as the ratio of net income divided by total assets. Higher profitability implies that the return on investment is higher than the cost of financing, which will favourably affect firm value (DeAngelo \& Masulis, 1980). Hypothesis 23: The return on assets positively affects firm value.

Dummy variables: In the sensitivity analysis, we measured the impact of growth opportunities on the relationship between debt and firm value. As a proxy for growth opportunities, we used two ratios: the "PER" ratio which is equal to the on earnings per share (Saibal Ghosh, 2007), and the ratio Market To Book "MTB" which is equal to the sum of market capitalization and long-term debt divided by total assets (McConnell \& Servaes, 1995). Saibal Ghosh (2007) and McConnell and Servaes (1995) define two dummy variables to distinguish between firms with high ratios of growth opportunities and firms with low ratios of growth opportunities. The first variable is equal to 1 if, for each year, the "PER" ratio is higher than the median of the "PER" ratios in our sample. Similarly, we define a second binary variable based on the "MTB" ratio.

\section{Empirical Results}

\subsection{Descriptive Statistics}

Table 2 provides descriptive statistics of our variables. The percentage of managerial ownership is equal on average to $35.52 \%$ which is not statistically significant. The debt ratio measured by "leverage" variable is on average equal to $48.29 \%$ and is significant. The average value of adjusted Tobin's $Q$ variable is equal to 1.375833 and is not statistically significant. For the control variables of the firm, the only significant variables at the $1 \%$ threshold, are "LogMve", "LogAssets" and "LogAge". Our sample is characterized by a relatively small proportion of tangible assets amounting to $19.55 \%$, making firms more opaque when signalling information. Finally, the average value of research and development is below $0.5 \%$, which is very low relative to the average level of 2 to $3 \%$ for other developed countries. This suggests that the intensity of amounts of research and development of French firms are still limited.

Table 1.Variables and expected signs

\begin{tabular}{lclc}
\hline Variables & Abbreviation & Formulation & Expected sign \\
\hline Managerial share ownership & MSO & Share of capital held by the board of directors & Dependant variable $(+/$-) \\
Leverage & DR & (LTD+STD)/TA & Dependant variable $(+/-)$ \\
Firm value & Adj Q & (MVE+LTD)/TA & Dependant variable $(+/-)$ \\
Firm size & SIZE & Ln(TA) and LN(MVE) & $+-/$ \\
Firm age & age & Ln(age) & $+/-$ \\
Research and development & R\&D & R\&D/TA & + \\
Tangible assets & Tangible & Fixed assets/TA & + \\
Cash flow & Cash flow & (NET income+DA)/TA & - \\
Tax savings & TS & EBIT/TA & - \\
Volatility & VOLTY & Standard deviation of changes in share price & - \\
Dividends & DIV & Total dividends/TA & + \\
Return on assets & ROA & Net income/TA & + \\
Dummy variable 1 & $\phi$ & 1 if PER $>$ median PER & Dummy variable 1 \\
\hline
\end{tabular}




\begin{tabular}{lcll}
\hline Dummy variable 2 & $\phi_{2}$ & 1 if MTB > median T+MTB & Dummy variable 2 \\
Oil sector & PET & 1 if oil sector & Dummy variable 3 \\
Trade sector & COMM & 1 if trade sector & Dummy variable 4 \\
Service sector & SER & 1 if service sector & Dummy variable 5 \\
Transportation sector & TRA & 1 if transportation sector & Dummy variable 6 \\
Industrial sector & IND & 1 if industrial sector & Dummy variable 7 \\
\hline
\end{tabular}

Note. TA: total assets. LTD: Long term debt. STD: Short term debt. MVE: Market value equity. DA: depreciation and amortization. EBIT: earnings before interests and taxes. PER: price earnings ratio (earnings per share). MTB: market to book ratio (MVE+LTD/TA).

Table 2. Descriptive statistics

\begin{tabular}{lc}
\hline Variables & Mean value \\
\hline Managérial share ownership & 0,355 \\
Leverage & $0,482^{* * *}$ \\
Firm value & 1,376 \\
LOG MVE & $19,632^{* * *}$ \\
LOG ASSETS & $19,838^{* * *}$ \\
Firm age & $3,336^{* * *}$ \\
Tangible & 0,195 \\
ROA & 0,0733 \\
R\&D & 0,0144 \\
Dividends & 0,0182 \\
Taxe Savings & 0,0439 \\
Cash flows & 0,0729 \\
Volatility & 0,568 \\
\hline
\end{tabular}

Note. ${ }^{* * *},{ }^{* * *}:$ significance at $10 \%, 5 \%$ and $1 \%$ levels respectively.

Table 3 shows the correlation analysis, reporting relatively low correlation between the endogenous variables.

Table 3. Coefficients de corrélations des variables dépendantes

\begin{tabular}{lccc}
\hline & Managerial ownership & Leverage & Firm value \\
\hline Managerial ownership & 1 & 0,1198 & 0,0258 \\
Leverage & 0,1198 & 1 & $-0,0785$ \\
Firm value & 0,0258 & $-0,0785$ & 1 \\
\hline
\end{tabular}

The correlation between our dependant variables, managerial ownership, leverage and Tobin's Q, is relatively low. In fact, the correlation between insider ownership and leverage is equal t $11.98 \%$ and that between allocation of shares (insider ownership) and Tobin's Q is $2.58 \%$. Furthermore, the correlation between debt and Tobin's Q is negative which contradicting the disciplinary role of debt.

\subsection{Interdependence between Debt, Firm Value and Managerial Ownership: Results and Interpretations}

To conduct our empirical study, like King and Santor (2008) that use two methods to estimate their models; Ordinary Least Squares method and data panels method, we used two methods of the "Data Panels" and "Triple Least Square" to estimate our models (Barnhart\& Rosenstein, 1998). The results are presented in Table 4.

Managerial ownership: The regression results confirm the nonlinear relationship between debt and managerial ownership under the data panels method. More specifically, the positive and significant coefficient of managerial ownership variable is consistent with the control effect between leverage and managerial ownership. This confirms the results of empirical studies of Kim and Sorensen (1986). However, the negative and significant coefficient

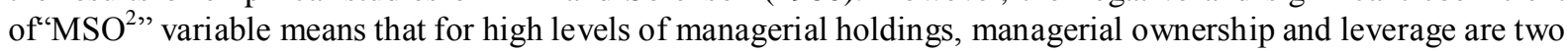
substitutable mechanisms for internal controls (Holderness \& Sheehan, 1988). In other words, for high values of managerial share ownership, the managers of French firms begin to deviate from the value maximizing behaviour. This result confirms hypothesis 1. In the third equation, like Miguel and Pindado (2001), we found a positive relationship between ownership and shareholders wealth. However, this relationship is negative for high MSO (first method). 
Table 4. Interdependence of managerial ownership, leverage and firm value

\begin{tabular}{|c|c|c|c|c|c|c|}
\hline & \multicolumn{3}{|c|}{ Simultaneous equations method } & \multicolumn{3}{|c|}{ Data panels method } \\
\hline & DR & MSO & ADJ Q & DR & MSO & ADJ Q \\
\hline $\mathrm{C}$ & 0.301 & $-1.155^{* * *}$ & 2.960 & 0.05 & $0.702^{* * * *}$ & $9.935^{* * *}$ \\
\hline MSO & 0.272 & & $15.985^{*}$ & $0.236^{* * *}$ & & $-1.129^{*}$ \\
\hline MSO $^{2}$ & 0.00620 & & -10.350 & $-0.201^{* *}$ & & $1.184^{*}$ \\
\hline ADJ Q & $-0.0444^{* * *}$ & $0.187^{* * *}$ & & 0.0035 & $0.0104^{* * *}$ & \\
\hline DR & & $3.634^{* * *}$ & $-22.057^{* * *}$ & & 0.0232 & $0.409^{* *}$ \\
\hline Ln (MVE) & & $-0.0508^{* * *}$ & & & $-0.0178^{* * * *}$ & \\
\hline $\operatorname{Ln}(\mathrm{TA})$ & 0.0141 & & $0.414^{* * *}$ & $0.0235^{* * *}$ & & $-0.407^{* * * *}$ \\
\hline LOGAGE & $-0.0371^{* * *}$ & $0.133^{* * *}$ & $-0.839^{* * * *}$ & $-0.0287^{* *}$ & -0.0051 & $-0.253^{* * * *}$ \\
\hline R\&D & -0.341 & $1.237^{* * * *}$ & -5.536 & $-0.501^{* * *}$ & 0.051 & $6.047^{* * *}$ \\
\hline Tangible & -0.0329 & 0.0793 & & $0.127^{* * *}$ & -0.0496 & \\
\hline Cash flow & 0.0306 & & & $-0.338^{* * *}$ & & \\
\hline TS & -0.0427 & & & $0.696^{* * * *}$ & & \\
\hline Volty & 0.00291 & $-0.0204^{* *}$ & & 0.000686 & 0.00114 & \\
\hline Dividend & & $0.605^{* *}$ & & & -0.240 & \\
\hline ROA & & & 2.657 & & & $4.16^{* * *}$ \\
\hline $\mathbf{R}^{2}$ & $9.32 \%$ & $15.51 \%$ & $14.46 \%$ & $7.26 \%$ & $18.73 \%$ & $15.44 \%$ \\
\hline CHIX DEUX & 856.06 & 500.18 & 230.79 & 119.66 & 34.36 & 469.85 \\
\hline
\end{tabular}

Note. ${ }^{* * *},{ }^{* * *}:$ significance at $10 \%, 5 \%$ and $1 \%$ levels respectively.

(Morck, Shleifer, \& Vishny, 1988; Stulz, 1988; McConnell \& Servaes, 1995; Davies, Hillier, \& McColgan, 2005). This results confirms hypothesis 2 . In other words, for low levels, managerial ownership has a negative and a significant effect on firm value. In contrast, for high values of managerial share ownership has a positive and a significant effect on firm value (Shleifer \& Vishny, 1986; La Porta, Lopez, Shleifer, \& Vishny, 2002). These results are valid only for the method "DATA PANELS". Therefore, we may conclude that for low levels of managerial share ownership, managers follow an entrenchment behaviour. however, for high levels, managers follow firm value maximization behaviour. Then, we may conclude that the alignment effect of interest (positive relationship) is checked for high levels of managerial ownership, and the entrenchment effect (negative relationship) is valid for low levels of managerial ownership (Morck, Shleifer, \& Vishny, 1988).

Leverage: Accordingly to hypothesis 3, we expect a positive and a significant relationship between leverage and managerial ownership. Furthermore, leverage has a negative and a significant effect on firm value, which contradicts the hypothesis 4 of agency costs on the disciplinary role of debt (Jensen, 1986). We can explain this contradictory result as follows. An increase in debt reduces the financial profitability of French companies because of the negative effect of leverage when the return on investment is weaker than the cost of debt, resulting, therefore, in a reduction in shareholder wealth. In addition, note that a higher amount of debt leads to an increase in financial expenses, leading a higher firm bankruptcy risk (Myers, 1977; Dimitris \& Psillaki, 2010) and reduces therefore the firm value. This result is consistent with the results obtained by McConnell and Servaes (1995) for US firms. In contrast, the results of the panel data method specify that leverage positively and significantly affects firm value (Jensen, 1986). This result joins as the empirical results of Grossman and Hart (1982). This result confirms hypothesis 4. In other words, leverage aligns the interests of managers and shareholders, which leads to maximizing firm value.

Firm value: Like in Alexei (2010), Tobin's Q, is negatively related to "leverage" and statistically significant at the $1 \%$ for the simultaneous equations method. This result confirms hypothesis 5 . In addition, firms with high growth opportunities in future tend to indebt less. This result is contrary to the hypothesis of disciplinary role of debt. This conclusion, which does not find the positive effect (not statistically significant) between these two variables under the data panels method, suggests that firms are trying to take investment opportunities. In the second equation, Tobin's Q has a positive and a statistically significant influence on managerial ownership, suggesting that managers seek to be satisfied by holding higher levels of capital share in large firms (Morck, Shleifer, \& Vishny, 1988; Chen \& Steiner, 2000). (hypothesis 6).

Firm size: Contrary to hypothesis 7, the coefficient of "SIZE" variable is positive and statistically significant at the $1 \%$ level. It is consistent with the hypothesis that firm size reduces the costs of bankruptcy, because the larger firms are more diversified. In the second equation, the coefficient of "LOGMVE" is negative and statistically significant (hypothesis 8). For the last model, According to the work of Servaes (1996), firm size is inversely related to firm 
value, indicating an absence of diversification. However, the first estimation method reported a positive relationship between size and firm value. This result confirms hypothesis 9 .

Firm age: Consistent with to hypothesis 10, the two estimation methods confirm that older firms are less leveraged. This result suggests that older firms tend to use more internal financing resources. In the second equation, firm age positively and significantly affects managerial ownership ( hypothesis 11), which means that the more a firm is old, the more it is better known, the more managers are interested in increasing their share of capital (Chun, Xin, \& Guanmin, 2014). For the latest model, firm age negatively and significantly affects firm value, contrary to what is expected (hypothesis 12).

Research and Development: Contrary to hypothesis 13, the coefficient on research and development variable is negative and statistically significant at the $1 \%$ for the data panels method. Only for the simultaneous equations method is Research and development variable is positively and significantly related to managerial ownership (hypothesis 14). This result means that an increase in research and development spending leads to higher managerial ownership in order to control behaviour of shareholders and managers. For the last model, Finally, Research and development variable has a positive and significant coefficients, only for the data panels method (Morck, Shleifer, \& Vishny, 1988; McConnell \& Servaes, 1990; Chen \& Steiner, 2000; and Chung \& Jo, 1996). This result corroborates hypothesis 15 .

Tangibility of assets: The estimation results also show a positive and a statistically significant coefficient of the variable "Tangible", only for the second method. this result confirms hypothesis 16 (Myers, 1977; Brealey \& Myers, 2000). This result is compared with that of the simultaneous equations method. In the second equation, the tangibility of the assets of the firm has a negative effect on managerial ownership for the data panels method. In fact, the negative effect of this variable means that the higher the ratio of tangibility of the firm is, the more it is transparent in the financial markets. This transparency allows the firm to find financial resources to projects, which will positively affect the profitability and hence firm value. This improvement in firm value makes it difficult for managers to get a share of the capital.

Cash Flow: Consistent with hypothesis 18, cash flows negatively affects firm debt ratio (Myers, 1984; and Myers $\&$ Majluf, 1984). Cash flow may involve an over-investment problem.

Tax savings: Contrary to the result of Guihai and Frank (2006), we find a positive effect of Tax Savings variable on leverage. This conclusion contradicts the argument that the more taxable income is, the higher the firm pays tax and is less interested in debt. This result rejects our hypothesis 19.

Volatility: Like in Frank and Goyal (2009), the simultaneous equations method shows a negative and a statistically significant relationship at the 5\% level between volatility and managerial ownership. This result can be interpreted as follows. Increased volatility means an increased risk. Since managers of a firm are risk averse, they will try to reduce their capital shares. This result confirms hypothesis 21 .

Dividends: Only for the data panels method, dividend variable negatively and significantly affect managerial ownership at the 5\% level, which supports the argument of "Free Cash Flow" theory (Jensen, 1986). This result rejects hypothesis 22 . The simultaneous equations method reports a contradictory result.

Return on assets: Similar to the results of Keith and Mark (1994), the effect of the variable "ROA" is positive and statistically significant only for the data panel method. This result corroborates hypothesis 23 .

\section{Sensitivity Analysis of the Results and Impact of Activity Sectors}

In this section, we examine the effects of industries, as well as growth opportunities on the relationship between debt and firm value.

\subsection{Debt and Firm Value and Effect of Activity Sectors}

Like Aggrawal and Zhao (2007), Barnhart and Rosentsein (1998), Schwartz and Aronson (1967), Scott (1972), Muradog and Sivaprasad (2011), we examine the effects of activity sectors on the disciplinary role of debt (Table 5). If the debt acts as a disciplinary mechanism, the leverage positively affects firm value. This conclusion is valid only for the simultaneous equations method for the oil, transport, trade and service sectors. However, for the data panels method, we record a negative and statistically significant effects for the industrial, transportation and trade sectors. However, the result for the oil sector is not statistically significant. 
Table 5. Role of activity sectors in explaining disciplinary role of debt

\begin{tabular}{|c|c|c|c|c|c|c|}
\hline & \multicolumn{3}{|c|}{ Simultaneous equations } & \multicolumn{3}{|c|}{ Data panels } \\
\hline & DR & MSO & ADJ Q & DR & MSO & ADJ Q \\
\hline $\mathrm{C}$ & $0.113^{*}$ & $0.553^{* * *}$ & $6.518^{* *}$ & 0.05 & $0.702^{* * *}$ & $9.964^{* * *}$ \\
\hline MSO & $0.393^{*}$ & & 20.759 & $0.236^{* * *}$ & & $-1.0685^{*}$ \\
\hline MSO $^{2}$ & -0.0527 & & -8.854 & $-0.201^{* *}$ & & $1.139^{*}$ \\
\hline ADJ Q & $-0.0230^{* * *}$ & $0.0739^{* * *}$ & & 0.0035 & $0.0104^{* * *}$ & \\
\hline DR & & $1.122^{* * * *}$ & $-39.930^{* * * *}$ & & 0.0232 & $0.653^{* * *}$ \\
\hline PET*DR & & & $3.499^{* * * *}$ & & & -0.166 \\
\hline IND*DR & & & 0.191 & & & $-0.618^{* * *}$ \\
\hline TRA*DR & & & $4.292^{*}$ & & & $-2.693^{* * *}$ \\
\hline COMM*DR & & & $3.948^{* * *}$ & & & $-1.100^{* *}$ \\
\hline SER*DR & & & $3.0811^{* * * *}$ & & & $1.233^{* * *}$ \\
\hline LOG MVE & & $-0.0522^{* * *}$ & & & $-0.0178^{* * *}$ & \\
\hline TAILLE & $0.0198^{* * *}$ & & $0.649^{* * *}$ & $0.0235^{* * *}$ & & $-0.409^{* * * *}$ \\
\hline LOGAGE & $-0.0339^{* * *}$ & $0.0608^{* * *}$ & $-1.289^{* * *}$ & $-0.0287^{* * *}$ & -0.0051 & $-0.249^{* * *}$ \\
\hline R\&D & $-0.537^{* * * *}$ & $0.265^{*}$ & $-21.994^{* * *}$ & $-0.501^{* * *}$ & 0.051 & $6.0005^{* * *}$ \\
\hline TANGIBLE & -0.00733 & $-0.141^{* * *}$ & & $0.127^{* * *}$ & -0.0496 & \\
\hline CASH FLOW & $-0.140^{* * * *}$ & & & $-0.338^{* * * *}$ & & \\
\hline NDTS & $0.291^{* * * *}$ & & & $0.696^{* * *}$ & & \\
\hline VOLTY & 0.000379 & -0.00383 & & 0.000686 & 0.00114 & \\
\hline DIVIDEND & & 0.113 & & & $-0.240^{*}$ & \\
\hline ROA & & & $-5.950^{* * *}$ & & & $4.167^{* * *}$ \\
\hline $\mathbf{R}^{2}$ & $5.68 \%$ & $12.78 \%$ & $15.55 \%$ & $7.26 \%$ & $18.73 \%$ & $23.49 \%$ \\
\hline CHIX DEUX & 579.40 & 596.61 & 1029.08 & 119.66 & 34.36 & 475.72 \\
\hline
\end{tabular}

Note. ${ }^{* * *}, * * *$ : significance at $10 \%, 5 \%$ and $1 \%$ levels respectively.

\subsection{Impact of Growth Opportunities on the Relationship between Debt and Firm Value}

Based on the theoretical work of Myers (1977), Jensen (1986), Shleifer and Vishny (1986), Stulz (1988, 1990) and Morck, Shleifer, and Vishny (1988), we try to test if the debt acts as a disciplinary mechanism for firms with growth opportunities.

Three samples are used for our test: the entire sample, a sample of firms with high growth opportunities and a sample of firms with low growth opportunities. For the entire sample, the results are presented in Table 6. For the two interaction terms, we found a disciplinary role of debt for firms with high growth opportunities. This result contradicts the result found by McConnell and Servaes (1995). This result means that for high levels of growth opportunities, an increase in the debt weakens retrenchment behaviour of managers and increases hence shareholder wealth. This result is similar to the result of the sub sample of firms with high values of growth opportunities only for the data panels

The results of the study of the influence of growth opportunities on the relationship between debt and firm value (Chen \& Zhao, 2006; Wu \& Wang, 2005), using the sub samples already defined above is presented in Table 7. These results show that for the simultaneous equations method, debt negatively and significantly influences firm value. However, for firms with low growth, and only under the data panels method, debt plays a disciplinary role, minimizing levels of agency costs related to "Free Cash Flow" and increasing shareholder wealth. The results are consistent with the findings of Hovakimian, Opler and Titman (2001) which emphasize that in the presence of limited opportunities for growth, higher debt ratio can add value by controlling for the "Free Cash Flow" problem. In contrast, according to the results of McConnell and Servaes (1995) for firms with high levels of growth opportunities, debt negatively affects firm value under the simultaneous equations method. This result is motivated by the theoretical work of Myers (1977) that highlight an inverse relationship between growth opportunities and debt. 
Table 6. Role of growth opportunities in explaining disciplinary role of debt for the entire sample

\begin{tabular}{|c|c|c|c|c|c|c|c|c|c|c|c|c|}
\hline & \multicolumn{6}{|c|}{ Price Earning Ratio } & \multicolumn{6}{|c|}{ Market To Book Ratio } \\
\hline & \multicolumn{3}{|c|}{ Simultaneous equations } & \multicolumn{3}{|c|}{ Data panels } & \multicolumn{3}{|c|}{ Simultaneous equations } & \multicolumn{3}{|c|}{ Data panels } \\
\hline & DR & MSO & ADJ Q & DR & MSO & ADJ Q & DR & MSO & ADJ Q & DR & MSO & ADJ Q \\
\hline $\mathbf{C}$ & -0.842 & $0.612^{* * *}$ & 4.00984 & 0.05 & $0.702^{* * * *}$ & $9.848^{* * *}$ & $-1.297^{*}$ & $0.768^{* * *}$ & 1.507 & 0.05 & $0.702^{* * *}$ & $8.0531^{* * *}$ \\
\hline MSO & 2.161 & & 9.118 & $0.236^{* * *}$ & & $-1.135^{*}$ & 3.352 & & $10.252^{*}$ & $0.236^{* * *}$ & & $-1.223^{* *}$ \\
\hline MSO $^{2}$ & -1.456 & & 1.708 & $-0.201^{* *}$ & & $1.188^{*}$ & -2.685 & & -3.969 & $-0.201^{* *}$ & & $1.196^{*}$ \\
\hline ADJ Q & $-0.046^{* * * *}$ & $0.0897^{* * *}$ & & 0.0035 & $0.0104^{* * *}$ & & $-0.0410^{* *}$ & $0.0756^{* * *}$ & & 0.0035 & $0.0104^{* * *}$ & \\
\hline DR & & $0.972^{* * *}$ & $-25.79^{* * *}$ & & 0.0232 & $0.387^{* *}$ & & $0.750^{* * *}$ & $-17.583^{* * *}$ & & 0.0232 & $-0.298^{*}$ \\
\hline$\phi_{2} * D R$ & & & $4.171^{* * * *}$ & & & 0.0324 & & & & & & \\
\hline$\phi_{3} * D R$ & & & & & & & & & $4.304^{* * * *}$ & & & $1.288^{* * * *}$ \\
\hline LOG MVE & & $-0.053^{* * *}$ & & & $-0.017^{* * *}$ & & & $-0.0529^{* * *}$ & & & $-0.0178^{* * *}$ & \\
\hline SIZE & $0.0558^{* * *}$ & & $0.455^{* * *}$ & $0.0235^{* * *}$ & & $-0.403^{* * *}$ & $0.0689^{* * *}$ & & $0.359^{* * *}$ & $0.0235^{* * *}$ & & $-0.310^{* * *}$ \\
\hline LOGAGE & $-0.059^{* * *}$ & $0.0643^{* * *}$ & $-0.934^{* * *}$ & $-0.0287^{* * *}$ & -0.0051 & $-0.252^{* * *}$ & $-0.0611 * * *$ & $0.0558^{* * *}$ & $-0.582^{* * *}$ & $-0.0287^{* *}$ & -0.0051 & $-0.230^{* * *}$ \\
\hline R\&D & -0.241 & 0.126 & $-13.94^{* * *}$ & $-0.501^{* * *}$ & 0.051 & $6.046^{* * * *}$ & -0.247 & 0.0838 & $-11.171^{* * * *}$ & $-0.501^{* * *}$ & 0.051 & $5.534^{* * *}$ \\
\hline TANGIBLE & 0.121 & $-0.130^{* * *}$ & & $0.127^{* * *}$ & -0.0496 & & 0.190 & $-0.154 * * *$ & & $0.127^{* * *}$ & -0.0496 & \\
\hline CASH FLOW & 0.0216 & & & $-0.338^{* * *}$ & & & 0.0329 & & & $-0.338^{* * *}$ & & \\
\hline NDTS & -0.102 & & & $0.696^{* * *}$ & & & 0.0343 & & & $0.696^{* * *}$ & & \\
\hline VOLTY & -0.0199 & -0.000043 & & 0.000686 & 0.00114 & & -0.0290 & 0.0000448 & & 0.000686 & 0.00114 & \\
\hline DIVIDEND & & 0.0307 & & & $-0.240^{*}$ & & & -0.154 & & & $-0.240^{*}$ & \\
\hline ROA & & & $-7.60^{* * * *}$ & & & $4.138^{* * * *}$ & & & $-6.298^{* * *}$ & & & $3.463^{* * *}$ \\
\hline $\mathbf{R}^{2}$ & $8.18 \%$ & $12.14 \%$ & $9.46 \%$ & $7.26 \%$ & $18.73 \%$ & $23.68 \%$ & $3.21 \%$ & $10.43 \%$ & $4.026 \%$ & $7.26 \%$ & $18.73 \%$ & $26.32 \%$ \\
\hline $\begin{array}{c}\text { CHIX } \\
\text { DEUX }\end{array}$ & 187.01 & 403.10 & 754.62 & 119.66 & 34.36 & 467.10 & 193.29 & 418.20 & 793.920 & 119.66 & 34.36 & 586.86 \\
\hline
\end{tabular}

Note. ${ }^{* * *},{ }^{* * *}$ : significance at $10 \%, 5 \%$ and $1 \%$ levels respectively.

Table 7. Role of growth opportunities in explaining disciplinary role of debt for the sub samples (firms with high and low growth opportunities)

\begin{tabular}{|c|c|c|c|c|c|c|c|c|c|c|c|c|}
\hline & \multicolumn{6}{|c|}{ Firms with high growth opportunities } & \multicolumn{6}{|c|}{ Firms with low growth opportunities } \\
\hline & \multicolumn{3}{|c|}{ Simultaneous equations } & \multicolumn{3}{|c|}{ Data panels } & \multicolumn{3}{|c|}{ Simultaneous equations } & \multicolumn{3}{|c|}{ Data panels } \\
\hline & DR & MSO & ADJ Q & DR & MSO & ADJ Q & DR & MSO & ADJ Q & DR & MSO & ADJ Q \\
\hline$\overline{\mathbf{C}}$ & 0.152 & $-1.477^{* * *}$ & 1.693 & 0.153 & $0.505^{* * * *}$ & $22.709^{* * *}$ & 0.155 & -0.453 & $20.874^{* *}$ & -0.0945 & $0.864^{* * *}$ & $9.492^{* * *}$ \\
\hline MSO & $1.145^{*}$ & & $26.389^{* * *}$ & $0.152^{*}$ & & 0.172 & 0.923 & & 11.488 & $0.335^{* *}$ & & -1.373 \\
\hline MSO2 & -1.0889 & & $-25.657^{* * *}$ & -0.0965 & & 0.359 & -0.585 & & 1.036 & $-0.317^{* *}$ & & 1.0823 \\
\hline ADJ Q & $-0.0482^{* * *}$ & $0.235^{* * *}$ & & $0.00605^{*}$ & $0.0122^{* * * *}$ & & $-0.0235^{* * *}$ & $0.0612^{* * *}$ & & 0.00230 & $0.00877^{*}$ & \\
\hline DR & & $4.680^{* * * *}$ & $-19.211^{* * * *}$ & & 0.0323 & $0.317^{*}$ & & $2.0236^{* * *}$ & $-44.832^{* * * *}$ & & 0.0159 & $0.509^{*}$ \\
\hline LOG MVE & & $-0.0675^{* * *}$ & & & $-0.0109^{* *}$ & & & $-0.0281^{* * *}$ & & & $-0.025^{* * *}$ & \\
\hline SIZE & $0.0172^{* * *}$ & & $0.366^{* * *}$ & $0.0175^{* * *}$ & & $-1.035^{* * *}$ & $0.0136^{* *}$ & & $0.239^{*}$ & $0.0301^{* * *}$ & & $-0.384^{* * *}$ \\
\hline LOGAGE & $-0.0331^{* * *}$ & $0.120^{* * *}$ & $-0.684^{* * *}$ & $-0.0320^{* * *}$ & 0.00305 & -0.164 & $-0.0332^{* *}$ & $0.0840^{* * *}$ & $-1.737^{* * *}$ & $-0.0317^{*}$ & -0.00887 & $-0.363^{* * *}$ \\
\hline $\mathbf{R} \& \mathbf{D}$ & $-0.578^{*}$ & $2.159^{*}$ & $-11.0693^{*}$ & $-0.683^{* * *}$ & 0.0536 & $4.659^{* * *}$ & $-0.478^{* * * *}$ & $0.871^{* * *}$ & $-27.022^{* * *}$ & -0.162 & 0.107 & $9.353^{* * * *}$ \\
\hline TANGIBLE & -0.0388 & $0.569^{* * *}$ & & $0.118^{* * *}$ & $-0.0662^{*}$ & & -0.0234 & -0.0366 & & $0.198^{* * * *}$ & -0.0211 & \\
\hline CASH FLOW & -0.0703 & & & $-0.236^{* * *}$ & & & -0.0566 & & & $-0.105^{*}$ & & \\
\hline NDTS & 0.173 & & & $0.462 * *$ & & & 0.105 & & & $0.695^{* *}$ & & \\
\hline VOLTY & -0.000283 & -0.0549 & & $0.0480^{*}$ & 0.0289 & & -0.00406 & -0.00176 & & -0.100 & -0.00174 & \\
\hline DIVIDEND & & $4.0210^{* * * *}$ & & & 0.0151 & & & 0.104 & & & $-0.325^{*}$ & \\
\hline ROA & & & 1.0971 & & & $2.273^{* * *}$ & & & -5.935 & & & $4.576^{* * *}$ \\
\hline $\mathbf{R 2}$ & $6.84 \%$ & $7.94 \%$ & $16.10 \%$ & $8.42 \%$ & $17.86 \%$ & $33.56 \%$ & $6.76 \%$ & $11.5 \%$ & $13.73 \%$ & $7.60 \%$ & $13.94 \%$ & $26.13 \%$ \\
\hline CHIX DEUX & 145.12 & 118.57 & 318.90 & 49.34 & 21.37 & 85.86 & 436.24 & 48.18 & 326.36 & 34.68 & 15.40 & 183.92 \\
\hline
\end{tabular}

Note. ${ }^{* * *},{ }^{* * *}$ : significance at $10 \%, 5 \%$ and $1 \%$ levels respectively. 


\section{Conclusion}

The study of the interaction between ownership structure, debt and shareholder wealth has attracted the attention of many theoretical studies. The aim of this paper is to empirically test the possible interrelationships between managerial ownership, leverage and firm value. Our empirical study is conducted on the French market. The empirical results are provided using two estimation methods: system of simultaneous equations and data panels methods. The empirical results show a non-linear effect between debt and managerial ownership for the data panels method. In addition, low levels of managerial ownership negatively affect firm value measured by Tobin's $\mathrm{Q}$, because of the existence of the entrenchment effect. However, for high levels of MSO, we record the opposite sign. This result can be explained by an alignment of interests between controlling shareholders and managers. This conclusion holds for the second estimation method. The simultaneous equations method supports a contradictory result. However, it appears that the debt and the managerial ownership are two complementary mechanisms to control managers' behaviour. Similarly, the disciplinary role of debt is valid, only, for the data panels method. As for the third variable, we found that firms with high levels of growth opportunities are less leveraged. However, a high firm value encourages managers to increase their capital shares. Finally, the sensitivity analysis of our results with respect to activity sectors, show that the disciplinary role of debt is valid for all sectors except the industrial sector.

\section{References}

Aggrawal, \& Xinlei, Z. (2007). The Leverage-Value Relationship Puzzle: An Industry Effects Resolution. Journal of Economics and Business, 59, 286-297. http://dx.doi.org/10.1016/j.jeconbus.2006.07.001

Alexei, V. (2010). Capital structure decisions: Evidence from deregulated industries. Journal of Financial Economics, 95, 249-274. http://dx.doi.org/10.1016/j.jfineco.2009.10.003

Ansgar, R., \& Christian, W. (2013). Determinants of ownership concentration in public firms: The importance of firm, industry and country-level factors. International Review of Law and Economics, 33, 1-14. http://dx.doi.org/10.1016/j.irle.2012.08.003

Ariffin, M., \& McGowan. (2010). Pyramidal structure, firm capital structure exploitation and ultimate owners' dominance. International Review of Financial Analysis, 19, 151-164. http://dx.doi.org/10.1016/j.irfa.2010.03.002

Barnhart, S. W., \& Rosenstein, S. (1998). Board Composition, Managerial Ownership, and Firm Performance: An Empirical Analysis. Financial Review, 33(4), 1-16. http://dx.doi.org/10.1111/j.1540-6288.1998.tb01393.x

Benartzi, S., Michaely, R., \& Thaler, R. (1997). Do changes in dividends signal the future or the past? Journal of Finance, 52, 1007-1034. http://dx.doi.org/10.1111/j.1540-6261.1997.tb02723.x

Brealey, R. A., \& Myers, S. C. (2000). Principles of Corporate Finance. New York: McGraw-Hill.

Chan, C. C., Lin, B. H., Chang, Y. H., \& Liao, W. C. (2013). Does bank relationship matter for corporate risk-taking? Evidence fromlisted firms in Taiwan. North American Journal of Economics and Finance, 26, 323-338. http://dx.doi.org/10.1016/j.najef.2013.02.008

Chen, C. R., \& Steiner, T. L. (2000). Tobin's Q, managerial ownership, and analyst coverage. Journal of Economics and Business, 52, 365-382. http://dx.doi.org/10.1016/S0148-6195(00)00024-2

Chen, L., \& Zhao, X. (2006). On the relation between the market-to-book ratio, growth opportunity, and leverage ratio. Finance Research Letters, Forthcoming. http://dx.doi.org/10.1016/j.frl.2006.06.003

Chun, C., Xin, C., \& Guanmin, L. (2014). What are the reliably important determinants of capital structure in China. Pacific-Basin Finance Journal, 30, 87-113. http://dx.doi.org/10.1016/j.pacfin.2014.06.001

Chune, Y. C., \& Kainan, W. (2014). Do institutional investors monitor management? Evidence from the relationship between institutional ownership and capital structure. North American Journal of Economics and Finance, 30, 203-233. http://dx.doi.org/10.1016/j.najef.2014.10.001

Chung, K. H., \& Jo, H. (1996). The impact of security analysts' monitoring and marketing functions on the market value of firms. Journal of Financial and Quantitative Analysis, 31, 493-512. http://dx.doi.org/10.2307/2331357

Chung, R., Firth, M., \& Kim, J. (2002). Institutional monitoring and opportunistic earnings management. Journal of Corporate Finance, 8, 29-48. http://dx.doi.org/10.1016/S0929-1199(01)00039-6

Claessens, S., Djankov, S., \& Lang, L. (2000). The separation of ownership and control in East Asian corporations. Journal of Financial Economics, 58, 81-112. http://dx.doi.org/10.1016/S0304-405X(00)00067-2 
David, \& Diane. (2006). Leverage and Investment In Diversified Firms. Journal of Financial Economics, 79, 317. http://dx.doi.org/10.1016/j.jfineco.2005.03.002

Davies, D., Hillier, D., \& McColgan, P. M. (2005). Ownership structure, managerial behaviour and corporate value. Journal of Corporate Finance, 11, 645-660. http://dx.doi.org/10.1016/j.jcorpfin.2004.07.001

DeAngelo, H., \& Masulis, R. W. (1980). Optimal capital structure under corporate and personal taxation. Journal of Financial Economics, 8, 3-29. http://dx.doi.org/10.1016/0304-405X(80)90019-7

Dimitris, M., \& Maria, P. (2010). Capital Structure, Equity Ownership and Firm Performance. Journal of Banking and Finance, 34, 621-632. http://dx.doi.org/10.1016/j.jbankfin.2009.08.023

Eckbo, B. E., \& Verman, S. (1994). Managerial ownership, voting power, and cash dividend policy. Journal of Corporate Finance, 1, 33-62. http://dx.doi.org/10.1016/0929-1199(94)90009-4

Ferreira, M. A., Massa, M., \& Matos, P. (2010). Shareholders at the gate? Institutional investors and cross-border mergers and acquisitions. Review of Financial Studies, 23, 601-644. http://dx.doi.org/10.1093/rfs/hhp070

Frank, M. Z., \& Goyal, V. K. (2009). Capital structure decisions: which factors are reliably important? Financial Management, 38, 1-37. http://dx.doi.org/10.1111/j.1755-053X.2009.01026.x

Grossman, S. J., \& Oliver, H. (1982). Corporate financial structure and managerial incentives. In J. McCall (Ed.), The Economics of Information and Uncertainty. University of Chicago Press, Chicago.

Guihai, H., \& Frank, M. S. (2006). The determinants of capital structure: Evidence from China. China Economic Review, 17,14-36. http://dx.doi.org/10.1016/j.chieco.2005.02.007

Gul, F. A. (1999). Government share ownership, investment opportunity set and corporate policy choice in China. Pacific-Basin Finance Journal, 7, 157-172. http://dx.doi.org/10.1016/S0927-538X(99)00004-9

Harris, M., \& Raviv, A. (1991). The Theory of Capital Structure. Journal of Finance, 46, 297-355. http://dx.doi.org/10.1111/j.1540-6261.1991.tb03753.x

Holderness, C. G., \& Sheehan, D. P. (1988). The role of majority shareholders in publicly held corporations: An exploratory analysis. Journal of Financial Economics, 20, 317-346. http://dx.doi.org/10.1016/0304-405X(88)90049-9

Hsu, G., \& Koh, P. (2005). Does the presence of institutional investors influence accruals management? Evidence from Australia. Corporate Governance: An International Review, 13, 809-823.

Hubert, de La B., \& Imen, L. (2012). Ownership structure and debt leverage: Empirical test of a trade-off hypothesis on French firms. J. of Multi. Fin. Manag., 22, 111-130.

Jensen, \& Meckling. (1976). Theory of The Firm: Managerial Behaviour, Agency Costs And Ownership Structure. Journal of Financial Economics, 3(4).

Jensen. M. C. (1986). Agency Costs of Free Cash Flow, Corporate Finance and Takeovers. The American Economic Review, 76(2), 323-329.

Kai, L., Heng, Y., \& Longkai, Z. (2009). Ownership, institutions, and capital structure: Evidence from China. Journal of Comparative Economics, 37, 471-490. http://dx.doi.org/10.1016/j.jce.2009.07.001

Keith, W. C., \& Mark, H. (1994). Goodwill, Profitability, and the Market Value of the Firm. Journal of Accounting and Public Policy, 13(2), 159-180.

Kim, W. S., \& Sorensen, E. H. (1986). Evidence on the impact of the agency costs of debt on corporate debt policy. Journal of Financial and Quantitative Analysis, 21, 131-144. http://dx.doi.org/10.2307/2330733

King, R., \& Santor, E. (2008). Family values: Ownership structure, performance and capital structure of Canadian firms. Journal of Banking and Finance, 32, 2423-2432. http://dx.doi.org/10.1016/j.jbankfin.2008.02.002

La Porta, R., Lopez, S. F., Shleifer, A., \& Vishny, R. W. (2002). Investor protection and corporate valuation. Journal of Finance, 57, 1147-1170. http://dx.doi.org/10.1111/1540-6261.00457

La Porta, R., Lopez-de-Silanes, F., \& Shleifer, A. (1999). Corporate ownership around the World. Journal of Finance, 54, 471-517. http://dx.doi.org/10.1111/0022-1082.00115

Lang, L. H. P., \& Stulz, R. M. (1996). Leverage, investment, and firm growth. Journal of Financial Economics, 40, 3-29. http://dx.doi.org/10.1016/0304-405X(95)00842-3

Lin, B. W., Lee, Y., \& Huang, S. C. (2006). R\&D intensity and commercialization orientation effects on financial performance. Journal of Business Research, 59, 679-685. http://dx.doi.org/10.1016/j.jbusres.2006.01.002 
MacKie-Mason, J. (1990). Do taxes affect corporate financing decisions?. Journal of Finance, 45, 1471-1493. http://dx.doi.org/10.1111/j.1540-6261.1990.tb03724.x

Mauer, D. C., \& Triantis, A. J. (1994). Interactions of Corporate Financing and Investment Decisions: A Dynamic Framework. The Journal of Finance, 49(4), 1253-1277.

McConnell, J., \& Servaes, H. (1990). Additional evidence on equity ownership and corporate value. Journal of Financial Economics, 27(2). http://dx.doi.org/10.1016/0304-405X(90)90069-C

Mcconnell, J., \& Servaes, H. (1995). Equity Ownership and the Two Faces Of Debt. Journal of Financial Economics, 39, 131-157. http://dx.doi.org/10.1016/0304-405X(95)00824-X

Miguel, D. A., \& Pindado, J. (2001). Determinants of Capital Structure: New Evidence From Spanish Panel Data. Journal of Corporate Finance, 7, 77-99. http://dx.doi.org/10.1016/S0929-1199(00)00020-1

Miroslav, M., Panikkos, P., \& Konstantin, I. (2013). On the determinants of SME capital structure in Central and Eastern Europe: A dynamic panel analysis. Research in International Business and Finance, 27, 28-51. http://dx.doi.org/10.1016/j.ribaf.2012.05.002

Modigliani, F., \& Miller, M. (1963). Corporate Income Taxes and the Cost of Capital: A Correction. American Economic Review, 53(3), 433-443.

Morck, R., Shleifer, A., \& Vishny, R. W. (1988). Management Ownership and Market Valuation: An Empirical Analysis. Journal of Financial Economics, 20, 293-315. http://dx.doi.org/10.1016/0304-405X(88)90048-7

Muradog, Y., \& Sivaprasad, S. (2011). Capital structure and abnormal returns. International Business Review, article in Press.

Myers, S. C. (1984). The capital structure puzzle. The Journal of Finance, 39(3), 575-592. http://dx.doi.org/10.2307/2327916

Myers, S. C., \& Majluf, N. S. (1984). Corporate financing and investment decisions when firms have information that investors do not have. Journal of Financial Economics, 13(2), 187-221. http://dx.doi.org/10.1016/0304-405X(84)90023-0

Myers. S. (1977). Determinants of Corporate Borrowing. Journal of Financial Economics, 5, 147-175. http://dx.doi.org/10.1016/0304-405X(77)90015-0

Opler, H. A. T., \& Titman. (2001). The debt equity choice: an analysis of issuing firm. Journal of Financial and Quantitative Analysis, 71, 517-540.

Peyer, U. C., \& Shivdasani, A. (2001). Leverage and internal capital markets: Evidence from leveraged $\begin{array}{lllll}\text { recapitalizations. Journal of } & \text { Financial } & \text { Economics, } & 59, & \text { 477-515. }\end{array}$ http://dx.doi.org/10.1016/S0304-405X(00)00094-5

Rajan, \& Zingales. (1995). What do we know about the capital structure? Some evidence from internationl data. Journal of Finance, 50, 1421-1460.

Saibal, G. (2007). Leverage, Managerial Monitoring and Firm Valuation: A Simultaneous Equation Approach. Research in Economics, 61, 84-98. http://dx.doi.org/10.1016/j.rie.2007.03.001

Schwartz, E., \& Aronson, J. (1967). Some surrogate evidence in support of the concept of optimal financial structure. Journal of Finance, 10-8. http://dx.doi.org/10.2307/2977296

Scott. D. (1972). Evidence on the importance of financial structure. Financial Management, 45-50. http://dx.doi.org/10.2307/3665143

Servaes, H. (1996). The value of diversification during the conglomerate merger wave. Journal of Finance, 51, 1201-225. http://dx.doi.org/10.1111/j.1540-6261.1996.tb04067.x

Shleifer, A., \& Vishny, R. (1986). Large Shareholders and Corporate Control. Journal of Political Economy, 94(3), 461-488. http://dx.doi.org/10.1086/261385

Stulz. R. (1988). Managerial Control Of Voting Rights: Financing Policies and The Market For Corporate Control. Journal of Financial Economics, 20(1), 25-54. http://dx.doi.org/10.1016/0304-405X(88)90039-6

Stulz. R.M. (1990). Managerial Discretion and Optimal Financing Policies. Journal of Financial Economics, 26, 3-27. http://dx.doi.org/10.1016/0304-405X(90)90011-N

Tai, V. W., Lai, Y. H., \& Lin, L. (2014). Local institutional shareholders and corporate hedging policies. North American Journal of Economics and Finance, 28, 287-312. http://dx.doi.org/10.1016/j.najef.2014.03.009 
Thomsen, S., \& Pedersen, T. (2000). Ownership structure and economic performance in the largest European $\begin{array}{llll}\text { companies. } \quad \text { Strategic } & \text { Management }\end{array}$ http://dx.doi.org/10.1002/(SICI)1097-0266(200006)21:6<689::AID-SMJ115>3.0.CO;2-Y

Tufano, P. (1996). Who manages risk? An empirical examination of risk management practices in the gold mining industry. Journal of Finance, 51(4). http://dx.doi.org/10.1111/j.1540-6261.1996.tb04064.x

Wang, M. (2014). Which types of institutional investors constrain abnormal accruals? Corporate Governance: An International Review, 22, 43-67. http://dx.doi.org/10.1111/corg.12044

William, B., Chao, C., \& Song, Z. (2013). Cash dividend policy, corporate pyramids, and ownership structure: Evidence from China. International Review of Economics and Finance, 27(2013), 445-464. http://dx.doi.org/10.1016/j.iref.2013.01.003

Wu, X., \& Wang, Z. (2005). Equity financing in a Myers-Majluf framework with private benefits of control. Journal of Corporate Finance, 11, 915-945. http://dx.doi.org/10.1016/j.jcorpfin.2004.04.001

Zingales, L. (1995). What Do We Know about Capital Structure? Some Evidence from International Data. The Journal of Finance, 50(5), 1421-1460.

\section{Copyrights}

Copyright for this article is retained by the author(s), with first publication rights granted to the journal.

This is an open-access article distributed under the terms and conditions of the Creative Commons Attribution license (http://creativecommons.org/licenses/by/3.0/). 